\title{
Application of Waste Plastic Oil as Alternative Fuel
}

\author{
Salim Walla. Salah. ${ }^{1}$, Seedahmed A. I. ${ }^{2}$ \\ 1,2 Department of Plastic Engineering, \\ College of Engineering \& Technology of Industries, \\ Sudan University of Science and Technology, \\ Sudan.
}

\begin{abstract}
Pyrolsis of plastic waste had become an important method to produce plastic waste oil as new supply of energy and alternative fuel system. This work was aimed to characterize the plastic waste oil resulted from pyrolsis. The use plastic waste oil was then used for two different applications.
\end{abstract}

Collected pyrolsis products using different reactor set up were analyzed and tested using GCMS, density, viscosity @ 40 0c, flash point , furan and dioxin and other test done by university of medical science, petroleum laboratories research and studies (PLRS) in Sudan, agricultural research center in Egypt and Egyptian petroleum research institute (EPRI).

Then the final product was used for fueling Tuk Tuk and the performance was found to be comparable to traditional fuel and even better than traditional fuel for TUK TUK as noticed that there a difference of $2 \mathrm{Km}$ when using $600 \mathrm{ml}$. Adding small amount of domestic oil to PP waste oil and reused again in Tuk Tuk gives excellent result. As increased the distance travelled by one compared to PP oil alone.

All tests results shows good results and confirm that the produced oil from HDPE, LDPE and PP alone is compared to gasoline specifications. Also the produced oil from mixture (HDPE+LDPE+PP) is compared to diesel specifications.

Key Words: Waste Plastic, Conversion, GCMS.

\section{INTRODUCTION:}

Waste plastic are one of the most promising resource for fuel because of its high heat of combustion and due to the increasing availability in local communities. Both plastics and petroleum derived fuels are hydrocarbons that contain the element of carbon and hydrogen. The difference between them is that plastic molecules have longer carbon chains than those in LPG, petrol and diesel fuel.

The different waste plastics were thermally cracked at different temperatures and then it was tried to measure the oil produced.

The conversion method of waste plastic into fuel depend on the types of plastic to be targeted and the properties. The type of plastic and their composition will condition the conversion process and will determine the combustion temperature for the conversion, the energy consumption required and the fuel quality out put.

\section{MATERIAL AND METHODS}

\subsection{Material:}

High density polyethylene (HDPE), polypropylene (PP), low density poly ethylene (LDPE), mixed of (500g HDPE +500 $\mathrm{g}$ LDPE) and mixed plastic (250 g HDPE+ $250 \mathrm{~g} \mathrm{LDPE}+$ $500 \mathrm{~g}$ PP). all the plastic material were shredding before using.

\subsection{Equipment:}

Reactor made from iron with different accessories, gas stove, jar, temperature watch and pipe.

\subsection{Methods:}

Vertical reactor V1:

1. Started the first trial at $11: 20$ am by adding $1 \mathrm{Kg}$ of HDPE until 3:50 pm, the product was approximately 70 $\mathrm{ml}$ with plastic remained unconverted shown in fig (3.1).

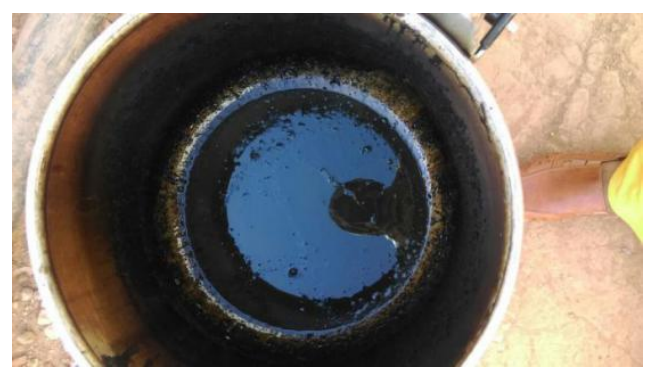

Figure (3.1): unconverted plastic

2. Putting $850 \mathrm{~g}$ of HDPE at 11:45 am, after half an hour the bubbles begin at the surface of water then the white gas observed after an hour and 14 minutes. The white gas automatically started and condense to oil in jar of water. After 2 hour the percentage of oil was little due to the degree of hotness and thickness of reactor, increasing the degree of hotness increased the gas subsequently, but the water became too hot so ice was added to help in cooling. An hour later the oil amount increased quickly. The procedure was stopped after 3 hours at 2:45 pm, then separated the oil from water by making a small hole at the bottom of jar allowing the water to pass out and the oil remain in the jar then put it in the glass flask shown in fig (3.2). 


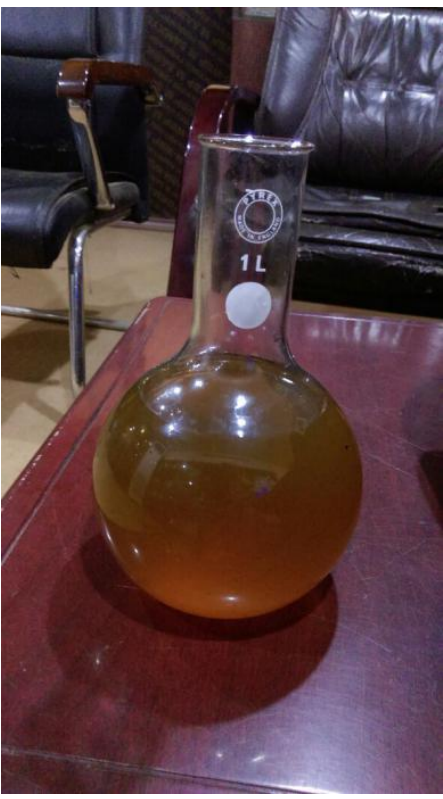

Figure (3.2): oil from 850g of HDPE

3. Repeat the process for anther $1 \mathrm{Kg}$ of HDPE and $1 \mathrm{Kg}$ of PP.

Vertical reactor with one watch V6

1. $1 \mathrm{~kg}$ of PP run about 1 hour from $11 \mathrm{am}$ to $12 \mathrm{pm}$, the final product was green oil from $170^{\circ} \mathrm{c}$ to $380 \mathrm{oc}$.

2. Repeat the process with the same material $1 \mathrm{~kg}$ of PP and same condition to check the unit doing well. the product was also green oil about $950 \mathrm{ml}$ in same temperature where the percentage of conversation was best one.

$3.1 \mathrm{~kg}$ mixed of PP and HDPE equally started at $12 \mathrm{pm}$ to $12: 45 \mathrm{pm}$, temperature in range $150^{\circ} \mathrm{c}$ to $350^{\circ} \mathrm{c}$, the final product was almost $950 \mathrm{ml}$ light green oil shown below in fig (3.3).

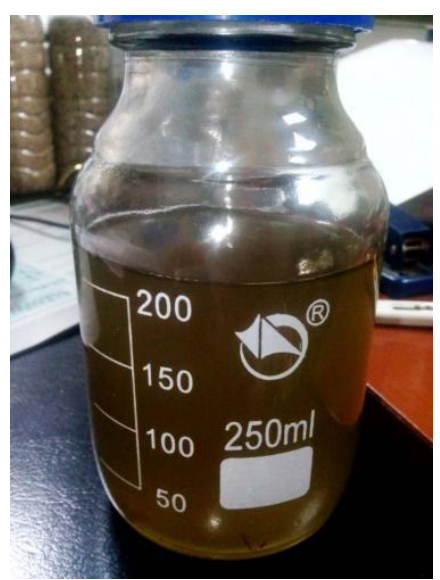

Figure (3.3): oil from PP and HDPE

4. $1 \mathrm{~kg}$ of mix LDPE and HDPE equally added to the unit started at $2: 45 \mathrm{pm}$ ended at $3: 20 \mathrm{pm}$, the gases started at $150^{\circ} \mathrm{C}$ to $350^{\circ} \mathrm{c}$ when the gases complete out the temperature also decrease gradually to know the processed done. where the result is pure and light yellow oil in spite of wax due to LDPE shown in fig (3.4) down. Separate the oil in glass and put in the office.
$5.1 \mathrm{~kg}$ mixed of $500 \mathrm{gm}$ of LDPE plus HDPE and $500 \mathrm{gm}$ of PP where added to unit at $11: 45 \mathrm{am}$ to $12: 30 \mathrm{pm}$ at same temperature, the result was $900 \mathrm{ml}$ green light oil due to the color of PP. We notice in this process increasing of the white gas coming so the losses in condensation bigger than others. Shown in fig (3.5)

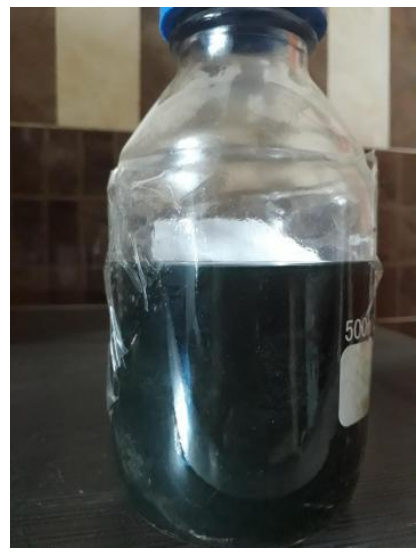

Figure (3.5): oil from mix of HDPE,LDPE and PP

- After i finished from every process and separate the oil, put it in the glass take it to the office for keeping until tested. When the oil exposed to cold air from A/C started to turn to wax completely in run (c), and some blocks and heavy dense oil in run (d) shown in figures below (3:6) and (3:7).

- I decided to return the wax and heavy viscous oil to the unit and running again to see what happen if we had pyrolsis in two stages.

- First we put PP oil from previous processed in unit V6 and run it at $11 \mathrm{am}$ to $11: 30 \mathrm{am}$ where the green heavy oil turn to very very light oil and the color was also very light green shown in figure below (3:7). The HDPE wax from previous processed put in the unit and run again for an hour gives light oil. Figure below (3:8).

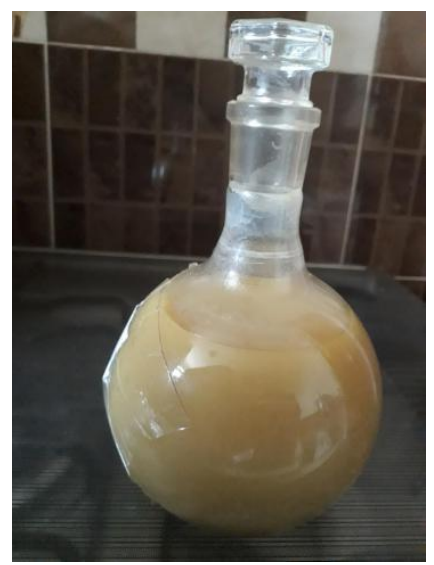

Figure (3.6): wax from run (c) 


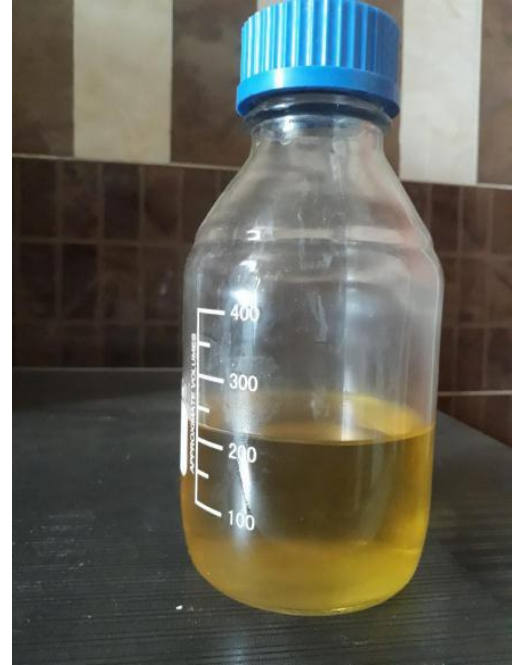

Figure (3.7): oil from PP wax

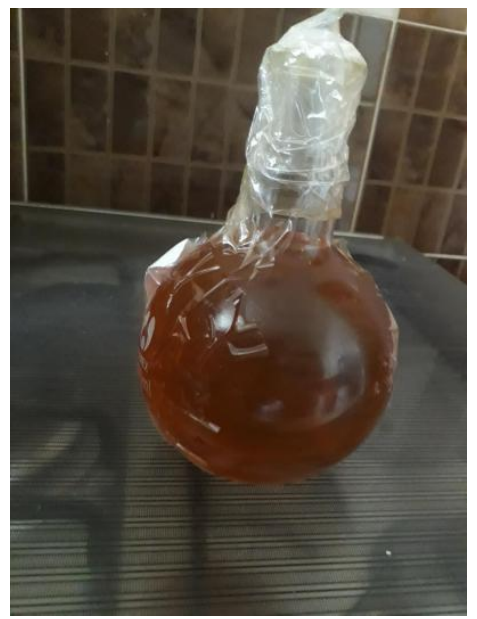

Figure (3:8): Oil from HDPE wax

\subsection{Testing plastic oil:}

The following tests were conducted according to the relevant standards as specified.

Plastic pyrolsis oil (liquid samples)

1) GCMS for PP oil sample done by university of medical science and technology.

2) Density at $150 \mathrm{oc}$ using ASTM D4052 (g /cm3).

3) Kinematic viscosity at 50oc using ASTM D445-12

4) Flash point using ASTM D93-12 ${ }^{\circ} \mathrm{C}$

5) Gross calorific value using ASTM D4868-00 or calculation $(\mathrm{Mj} / \mathrm{Kg})$

6) Viscosity @ 40oc using ASTM D445 cSt

7) Water by distillation using ASTM D95 (V /V)

8) Micro Carbon residue using ASTM $4530(\mathrm{Wt} \%)$

All the above tests done by petroleum laboratories, research and studies (PLRS) in Sudan.
9) Dioxin and furan test according to PCDD /PCDF method which determination of tetra -through Octa- chlorinated dioxins and furans by isotope dilution HRGC /MS. EPA 1613-B(1994). tests done by Agricultural research center, Egypt.

10) Total sulfur content using ASTM D4294 ( $\mathrm{mg} / \mathrm{l}$ ) and Total lead content using ASTM D4691 (mg /l) were done by Egyptian petroleum research institute (EPRI), EPRI central analytical labs.

\subsection{Application of the plastic waste oil:}

Three trials were made to apply the plastic waste oil as fuel to Tuk Tuk, these were as following:

I. $\quad 500 \mathrm{ml}$ of the resulting HDPE oil was used as fuel to replace the traditional fuel of tuk tuk. And the distance travelled by the plastic oil were $13 \mathrm{Km}$ and the domestic fuel were $10 \mathrm{Km}$. Fortunately, tuk tuk traveled distance 1.3 times the distance travelled by same amount of traditional fuel.

II. Also another $600 \mathrm{ml}$ of PP oil used in tuk tuk travelled times the distance travelled by same amount of traditional fuel. Which was less than the first trial due to the density of it was less than above oil where the burning characteristics was fast.

III. Small amount of domestic oil used to be added to benzene was added to PP oil and reused again in tuk tuk the result being very excellent. Where the distance differ between PP oil plus oil and the PP oil only $1 \mathrm{Km}$, and the PP oi-l and traditional fuel for tuk tuk were $2 \mathrm{Km}$.

IV. $100 \mathrm{ml}$ of mixed plastic oil (HDPE, LDPE, PP) where adding to the cresset and lighting for 9 hours.

RESULTS AND DISCUSSIONS

Table (4.1): of Conversion percentages:

\begin{tabular}{|l|l|l|}
\hline Material & Reactor type & Conversion percentage $\%$ \\
\hline $850 \mathrm{Kg}$ OF HDPE & Vertical reactor V2 & $695 / 850 * 100=81.7 \%$ \\
\hline $1 \mathrm{Kg}$ of HDPE & Vertical reactor V2 & $950 / 1000 * 100=95 \%$ \\
\hline $1 \mathrm{Kg}$ of PP & $\mathrm{V} 2$ & $822.7 / 1000 * 100=82.2 \%$ \\
\hline $1 \mathrm{Kg}$ of PP & $\mathrm{V} 6$ & $950 / 1000 * 100=95 \%$ \\
\hline $\begin{array}{l}1 \mathrm{Kg} \text { of mixed (PP and } \\
\mathrm{HDPE})\end{array}$ & $\mathrm{V} 6$ & $950 / 1000 * 100=95 \%$ \\
\hline $\begin{array}{l}1 \mathrm{Kg} \text { of mixed (HDPE } \\
\text { and LDPE) }\end{array}$ & $\mathrm{V} 6$ & $960 / 1000 * 100=96 \%$ \\
\hline $\begin{array}{l}1 \mathrm{Kg} \text { of mixed (HDPE, } \\
\mathrm{LDPE} \text { and PP) }\end{array}$ & $\mathrm{V} 6$ & $900 / 1000 * 100=90 \%$ \\
\hline
\end{tabular}

- The result of GCMS for PP oil sample done by university of medical science and technology was C7 to $\mathrm{C} 13$, which in the range of benzene. 
Table (4.2): Test of sulfur, lead content, dioxin and furan content:

\begin{tabular}{|l|l|l|l|}
\hline Sample ID & $\begin{array}{l}\text { Sulfur content } \\
\mathrm{mg} / \mathrm{l}\end{array}$ & $\begin{array}{l}\text { Lead content mg } \\
/ 1\end{array}$ & $\begin{array}{l}\text { Dioxin and furan } \\
\text { (PCDD } \\
\text { PCDF) }\end{array}$ \\
\hline HDPE oil & Nil & $>0.375$ & 0.38 \\
\hline PP oil & Nil & $>0.3650$ & - \\
\hline
\end{tabular}

- This result done in Egypt which was being very difficult to do again for other running experiment. For PCDD /PCDF the measurement uncertainty expressed as expanded uncertainty (at $95 \%$ confidence level) is within the range $+50 \%$

Table (4.3): The tests result was for PP oil and HDPE oil run from $\mathrm{V} 1$ :

\begin{tabular}{|c|c|c|}
\hline $\begin{array}{c}\text { Sample } \\
\text { ID }\end{array}$ & $\begin{array}{c}\text { Density } \\
\text { @ } 150 \mathrm{~g} \mathrm{~g} \\
/ \mathrm{cm} 3\end{array}$ & FT-IR \\
\hline $\begin{array}{c}\text { HDPE } \\
\text { oil }\end{array}$ & 0.7884 & $\begin{array}{c}\text { According to the scan, saturated (-C-H) } \\
\text { stretching peaks were found, }(\mathrm{C}=\mathrm{C}) \text { were } \\
\text { found, methyl group }(-\mathrm{CH} 3) \text { was found and } \\
\text { methylene group }(-\mathrm{CH} 2-) \text { also was noticed. }\end{array}$ \\
\hline PP oil & 0.7781 & $\begin{array}{c}\text { According to the scan, saturated (-C-H) } \\
\text { stretching peaks were found, }(\mathrm{C}=\mathrm{C}) \text { were } \\
\text { found, methyl group }(-\mathrm{CH} 3) \text { was found and } \\
\text { methylene group (-CH2-) also was noticed. }\end{array}$ \\
\hline
\end{tabular}

Table (4.4): test

\begin{tabular}{|c|c|c|c|c|c|}
\hline Test name & Unit & $\begin{array}{l}\text { HDPE } \\
\text { oil } \\
\text { pyrolsis } \\
\text { twice }\end{array}$ & $\begin{array}{l}\text { PP oil } \\
\text { pyrolsis } \\
\text { twice }\end{array}$ & $\begin{array}{l}\text { HDPE + } \\
\text { LDPE oil } \\
\text { pyrolsis } \\
\text { twice }\end{array}$ & $\begin{array}{l}\text { HDPE+LD } \\
\text { PE+PP oil } \\
\text { pyrolsis } \\
\text { twice }\end{array}$ \\
\hline $\begin{array}{l}\text { Flash } \\
\text { point }\end{array}$ & ${ }^{\circ} \mathrm{C}$ & $<40$ & $<40$ & 60 & $<40$ \\
\hline $\begin{array}{l}\text { Density } \\
\text { @ } 15^{\circ} \mathrm{c}\end{array}$ & $\begin{array}{l}\mathrm{g} \\
/ \mathrm{cm} 3\end{array}$ & 0.7968 & 0.7739 & 0.7966 & 0.7883 \\
\hline $\begin{array}{l}\text { Calorific } \\
\text { value } \\
\text { gross }\end{array}$ & $\begin{array}{l}\mathrm{Mj} \mathrm{/} \\
\mathrm{Kg}\end{array}$ & 44.838 & 45.039 & 44.847 & 44.912 \\
\hline $\begin{array}{l}\text { Viscosity } \\
\text { @ } 40^{\circ} \mathrm{c}\end{array}$ & $\mathrm{cST}$ & 3.173 & 1.508 & 2.826 & 2.020 \\
\hline $\begin{array}{l}\text { Water } \\
\text { content by } \\
\text { distillation }\end{array}$ & $\mathrm{V} / \mathrm{V}$ & 0.00 & 0.00 & 0.00 & 0.00 \\
\hline $\begin{array}{l}\text { Carbon } \\
\text { residue } \\
\text { MCR }\end{array}$ & $\begin{array}{l}\mathrm{Wt} \\
\%\end{array}$ & 0.4 & 0.1 & * & $*$ \\
\hline $\begin{array}{l}\text { Sulfur } \\
\text { content }\end{array}$ & $\% \mathrm{~m}$ & $*$ & $*$ & 0.122 & 0.071 \\
\hline
\end{tabular}

Sulfur content test for HDPE oil and PP did not done due to technical reasons at that time. Also MCR test for HDPE+LDPE oil and mixed oil did not done.

\section{CONCLUSION}

- From the experimental studies it is clear that the waste plastic oil is a good and also can be used.

- The product can used as fuel for TUK TUK which was better from traditional benzene and more efficiency.

- Also can used as a source of lighting for traditional cresset for rural areast.

\section{RECOMMENDATION}

- More tested like $\mathrm{CO}, \mathrm{CO} 2$ and $\mathrm{NO}_{\mathrm{X}}$ concentrations in the plastic oil.

- Poly ethylene terephthalate (PET) and tires should be used in future work studies.

\section{REFERENCE}

[1] United Nations Environmental Programme, (2009) "converting waste plastic into a resource", compendium of technology, Japan,.

[2] http://www.astm.org $>$ Standards $>$ D 4052

[3] http://www.astm.org $>$ Standards $>$ D 445-12

[4] http://www.astm.org $>$ Standards $>$ D93-12

[5] http://www.astm.org $>$ Standards $>$ D4868-00

[6] http://www.astm.org $>$ Standards $>$ D445

[7] http://www.astm.org $>$ Standards $>$ D95

[8] http://www.astm.org $>$ Standards $>$ D4530

[9] http://www.astm.org $>$ Standards $>$ D4691

[10] Conversion of waste plastics into alternative fuel , "Rao* , 4.(8): August, 2015” , “Dr.L.Nageswara Rao*, J L Jayanthi , D.Kamalakar" 


\section{AUTHOR BIBLOGRAPHY}

\begin{tabular}{|l|l|}
\hline & $\begin{array}{l}\text { Walla Salah Salim Awad Elkareem } \\
\text { The first author did his B.Sc. Degree in plastic engineering at Sudan University of Science and Technology } \\
\text { (SUST), Khartoum Sudan in 2006. M.Sc. Degree in wood plastic composite at SUST in 2014. currently, she is } \\
\text { working towards the PhD. degree in plastic engineering at SUST. The research include material, method and } \\
\text { result of tests. Ms. Walla Salah Salim is a lecture in SUST, Eng, college now. }\end{array}$ \\
\hline $\begin{array}{l}\text { Professor Seedahmed, A.I } \\
\text { Chemistry at (U of G), Sudan in 1991. Science (U of G), and PhD degree in Polymer and Plastic Engineering at } \\
\text { Sudan University of Science and Technology (SUST), Khartoum, Sudan in 2005. Plastic and Polymers } \\
\text { recycling, Analysis of Polymer Composites an advanced Polymer material and applications. } \\
\text {.Dean College of Engineering SUST } \\
\text { Superviced 10 Ph D students so far (six were graduated and four proceeding) } \\
\text { Published so far 22 reviewed papers and two books. }\end{array}$ \\
\hline
\end{tabular}

